\title{
Poetic Texts in Polish Heritage Language Classes
}

\author{
Anna Gąsienica Byrcyn \\ Saint Xavier University
}

\begin{abstract}
The use of poetic texts in heritage Polish composition classes offers a resourceful, motivating, and original way of learning the language and culture, primarily by mastering writing skills and understanding Poland's rich and complex culture. Moreover, poetic texts give an aesthetical beauty and moral values, and the students discover universal truths during their readings and discussions. A chosen poem, such as Adam Mickiewicz's "Lelije" (Lilies), Teofil Lenartowicz’s "Złoty kubek" (A Golden Cup), or Bolesław Leśmian's "Urszula Kochanowska" (Ursula Kochanowska), is presented in class for listening exercises, reading, recitation, discussion, and especially creative writing. The students are introduced to the captivating genre of poetry and learn about the cultural and historical content of this work. Then, they write their poem or a composition on the introduced theme. The assessment consists of the student's originality, the content of the paper, the organization of the paper, and the employment of correct grammatical sentence structure and vocabulary.

Consequently, poetic texts immersed in Polish intertextual space are open and may be read in many ways, beyond their initial context, presenting many fascinating interpretations and offering many intellectual attractions. A poem is an excellent learning source for the creativity stage in the art of writing, transmuting elements of the past Polish culture and literature in modern language classes. Students write their own intriguing stories, focusing on their knowledge of the language, and using resourcefulness and creativity.
\end{abstract}

Keywords: Polish, heritage language, poetry in language teaching and learning, poetry and writing skills.

$\mathrm{T}$

eaching Polish language to heritage students involves interactions with culturally and linguistically diverse groups of learners. Most heritage classes are multilevel, with students who speak Polish fluently, apply highly sophisticated vocabulary, but write and spell poorly. Additionally, there are heritage students who can speak only the subdialect learned from their parents and grandparents, or who make use of their "home language" - a mixture of a subdialect and a standard Polish languagewithout differentiating between them. There are also heritage students who mastered their Polish language skills to perfection by having close contact with native Polish speakers, understanding the Polish culture well, and visiting Poland on a regular basis. Many heritage speakers have a well-tuned ear to Polish sounds since they heard them in the pre-natal stage, throughout 
their childhood, and in their early youth while attending Polish Saturday Schools. These students have developed rather good listening and pronunciation skills, but nonetheless they lack good writing skills. Consequently, most heritage students need to acquire a solid foundation in Polish grammar and spelling to achieve proficiency in writing. For this reason, a focus on reading and writing is crucial at all levels of heritage language courses.

In the Polish program discussed here, students begin to develop writing skills early in elementary heritage Polish language courses, by composing 57 simple sentences about their interests. Following these basic writing activities, students move to writing brief notes, cards, invitations, and compositions describing pictures cut out from current Polish magazines, or they create new stories about the scenes captured in the photos. Various writing tasks are very effective for multilevel classes because each language learner can express his/her knowledge of lexicon, syntax, and genre. For listening activities and practicing of sound systems, an introduction to classic children's poems written by Jan Brzechwa or Julian Tuwim is an excellent way to practice Polish sound systems and expand vocabulary. Brzechwa's poem "Dzik" (Boar) is suited to a practice of the sounds [dz], [dzi], and [drz]. Brzechwa wrote a series of such short poems about animals, for instance "Lis" (Fox), "Żubr" (Bison), "Struś" (Ostrich), "Żółw" (Turtle), and "Słon" (Elephant). Students learn the names of animals and practise Polish sound systems with these entertaining poems. Usually, they like animals, so they often memorize the poems. Polish heritage learners also compose short paragraphs about their own pets, or they describe their favourite animals.

Heritage students continue the writing and study of grammar in intermediate Polish heritage language courses. At this level, students keep a journal in which they write entries on topics connected with specific lesson themes, applying new vocabulary and learned grammatical structures. In addition, they work on longer writing projects dedicated to Polish music, a chosen Polish city, or their favourite place in Poland, actively researching their topics. Occasionally, students listen to Polish songs with lyrics illustrating such grammatical topics as instrumental, locative, accusative cases, the verb + genitive case, present and past tenses, conditional mood, and participles, as found in Anna Majkiewicz and Jolanta Tambor's book Śpiewająco po polsku (Singing in Polish). They also read Polish children's poems. "Okulary" (Eyeglasses), "Mucha" (Fly), and "Engliczek pentliczek" (Eeny, Meeny, Miny, Moe) focus on the locative case; "Idzie Grześ przez wieś" (Greg Is Walking Through the Village) and "Tańcowała igła z nitką" (Dance of a Needle with a Thread) show the use of verbs; the poem "Jak biedronka zgubiła kropki" (How a Ladybug Lost Her Dots) employs the days of the week; and "Warzywa" (Vegetables) offers excellent examples on the 
accusative singular and the names of vegetables which can lead to a discussion of favourite Polish food and healthy eating habits. All these poems are easily accessible online or in anthologies of children's poetry.

In Polish conversation and composition classes, heritage language learners review their spelling by working with Ewa Lipińska's book Nie ma róży bez kolców (There Are No Roses Without Thorns). Students read extensively to build their vocabulary. The series of adaptations of Polish masterpieces Czytaj po polsku (Read in Polish) is used for readings. More determined and striving heritage speakers study idioms found in Anna Pięcińska's book Co raz wejdzie do głowy-już z niej nie wyleci, czyli frazeologia prosta i przyjemna (What Once Enters the Head-It Won't Leave It, or Simple and Pleasant Phraseology). In addition, students read challenging articles devoted to current news about Polish culture or literature taken from Tygodnik Powszechn (Weekly News), and later they write summaries of or compositions on relevant topics. Students also write film and book reviews by referring to Andrzej Ruszer's Oswoić tekst. Podręcznik kompozycji i redakcji testów użytkowych (To Tame the Text. Textbook of Compositions and Editing of Useful Texts) and Marek Wójcikiewicz's Piszę, więc jestem. Podręcznik kompozycji i redakcji tekstów (I Write, Therefore I Am. Textbook for Composing and Editing Texts). Subsequently, in the program discussed, language teaching is organized around Polish culture, purposeful tasks, everyday chores, and academic situations that the language users encounter or will experience in their lives.

After completing the conversation and composition classes, motivated and ambitious heritage students enroll in the Advanced Polish Composition and Conversation class, a fourth-year Polish language class. At the very beginning of this course, I, as an instructor, play a game of cultural association in order to determine who among the enrolled students is familiar with particular masterpieces of Polish literature or certain aspects of Polish culture. Primarily, I ask my heritage students to tell me what cultural associations come to mind when they hear words, such as maliny raspberries, lilie - lilies, or fortepian - grand piano, etc. Usually, students never mention Juliusz Słowacki's well-known tragedy Balladyna (Balladina) or Bolesław Leśmian’s poem "W malinowym chruśniaku” (In the Raspberry Thicket) when they hear the word maliny (raspberries). Most of them connect the grand piano with Frédéric Chopin, but hardly ever with Cyprian Kamil Norwid's outstanding poem "Fortepian Chopina" (Chopin's Piano). Clearly, most heritage students do not associate lilies with Adam Mickiewicz's ballad "Lilije” (Lilies) or Słowacki's play Lilla Weneda because they have never encountered these particular works and other important literary texts during their twelve years of studying at a Polish Saturday School. Consequently, I add several masterpieces, including Mickiewicz's ballad "Lilies," Teofil Lenartowicz’s syllabotonic poem “Złoty kubek" (A 
Golden Cup) based on the old Polish carol, and Czesław Miłosz's "Orfeusz i Eurydyka" (Orpheus and Eurydice) to the fourth-year Polish syllabus in order to immerse heritage learners in Polish high culture literary texts, thereby extending the list of interesting and challenging topics for students.

The question of using literature in learning and teaching Polish has been discussed by some scholars. Anna Seretny studies how literature could be used in a Polish language classroom and what role it plays in language learning and in teaching Polish as a second language. Romuald Cudak discusses literature studies in a Polish foreign language classroom and illustrates how various Polish poems may be used in a language class ("Edukacja Literacka"). In one of his studies, Cudak offers students' work as a result of incorporating literary texts into language learning and teaching. He presents an interesting composition written by a student on the theme of lilies, which was inspired by Mickiewicz's ballad:

Miałam kolegę Tomka, który mieszkał dwa piętra wyżej ode mnie. Mieszkał sam, ale miał fajną dziewczynę, która studiowała w Katowicach i czasami przyjeżdżała do niego. Miała odwiedzić go $\mathrm{w}$ weekend, więc Tomek posprzątał mieszkanie i zdecydował się pójść na targ, żeby kupić kwiatki. Bo chciał ucieszyć swoją dziewczynę. Na targu babcie sprzedawały lilie. Sprzedawały oczywiście „na czarno”, bo lilie są rzadkimi kwiatami i handel nimi jest zabroniony. Na targu było dużo mniej milicji, ale Tomek zdecydował się zaryzykować i kupił pięćdziesiąt lilii, bo były świeże i miały jeszcze zamknięte kwiaty, Przyniósł kwiaty do domu. Jaki był zadowolony!

Długo szukał wazonu, gdyż lilii było tak dużo, że nigdzie nie mogły się zmieścić. Wieczorem poszedł sobie spać, czekając na dziewczynę. W nocy pąki kwiatów się pootwierały. Lilie miały mocny i specyficzny zapach i było ich tak dużo, że zabiły pana. Zbrodnia to oczywiście niesłychana. Tak skończył życie mój sąsiad, ale jego dziewczyna i tak nie przyjechała. Spotkała innego chłopaka i się w nim zakochała. (Cudak, "Tekst Poetycki" 93)

(I had a friend named Tom who lived two floors above me. He lived alone, but he had a nice girlfriend who studied in Katowice and visited him occasionally. She was supposed to visit him over the weekend, so Tom cleaned up his apartment and decided to go to the market to buy some flowers. He wanted to surprise his girlfriend. At the market the old grannies were selling lilies. They were selling them on the "black market" because the sale of lilies was forbidden. There were only a couple of militiamen at the market, so Tom decided to take a risk and bought fifty lilies because they were fresh and had closed blossoms. He brought the flowers home. He was overjoyed.

He looked for a vase for a long time because he could not find a perfect one that would fit so many lilies. In the evening he fell asleep while waiting for his girlfriend. At night the lilies' blossoms opened up. The lilies had a strong and distinctive fragrance. There were so many of them that they killed the guy. 
This clearly is an unheard of story. In such a way, my neighbour ended his life.

His girlfriend never showed up. She met another man and fell in love.)

In my fourth year Polish class, I follow the example of Cudak and introduce Mickiewicz's "Lilies" as one of the literary texts. Please note that the main textbook for this course is $\mathrm{Na}$ łamach prasy [In the Press] by Bogusław Kubiak. It has a limited choice of literary texts, which are mostly legends and articles on Polish traditions with lists of synonyms and antonyms.

Mickiewicz's ballad "Lilies" is based on a folk song entitled "Stała się nam nowina" (A New Thing Happened to Us). A woman killed her husband, buried his body in the garden, and planted lilies on his grave (Mickiewicz 178). Mickiewicz modified the original version for his own artistic purposes creating a ballad of 354 lines. The folk song contains remnants of the past, dating back to the eleventh century when King Bolesław Śmiały was absent for so long on his expedition to Kyiv that the wives of Polish knights became unfaithful during their absence (Mickiewicz 167). The lilies in Mickiewicz's ballad acquire a symbolic significance. They become the instrument of divine punishment. Much of the story is presented through dialogues, so that "Lilies" has the effect of a play. The speeches of the characters are brief, direct, and quick. Mickiewicz left elaborate meter in favour of seven and eight syllable lines that rhyme sometimes as couplets, sometimes as quatrains. After the discussion of this unusual ballad, students watch the video adaptation of Mickiewicz's ballad, created by Tadeusz Woźniak and entitled Ballady polskie (Polish Ballads). The intersemiotic variation of the ballad reinforces certain parts of the poem and helps students to understand it better, making the class more thrilling. The clip is viewed, discussed in class, and compared to the original text. Next, the students read and study equally striking poems written by the contemporary Polish poet Miron Białoszewski entitled "Lilie" (Lilies). Białoszewski's poem is composed of only 7 lines. The title and a line taken from Mickiewicz's ballad "Unheard of crime! A wife slays her husband!" (Zbrodnia to niesłychana) (Cudak, "Tekst Poetycki" 92) are direct allusions to Mickiewicz's work. However, Białoszewski's poem tells a story about an illegal purchase of lilies on the black market by the poet and an attempt on his life. Although the poem has a horrifying mood, it is a literary pun on the romantic literature. It also presents Polish reality during the time of Communism when the black market flourished. Then, heritage learners read Agnieszka Kuciak's "Pani zabija pana. Ballada elektroniczna" (A Wife Murders Her Husband. An Electronic Ballad), an equally alarming poem inspired by Mickiewicz's ballad, dealing with the issue of crime and punishment. Kuciak's poem is yet another allusion to Mickiewicz's "Lilies." Kuciak, just as Białoszewski, takes the famous line from Mickiewicz: "Zbrodnia to niesłychana, Pani zabija pana" 
(Unheard of crime! A wife slays her husband!). In her poem, the wife murders her husband for his body parts, which she tries to sell on the Internet, but her husband's brother discovers her horrendous act and informs the FBI. She is sentenced to death. Her electric chair, lovely as a lily, awaits her. Consequently, the verses on lilies referring to the themes of violence, crime, and punishment lead later on to sets of stories, compositions, or poems created by students, comparable to the following one, written by a Polish heritage learner as an assignment in my Polish Advanced Composition and Conversation class:

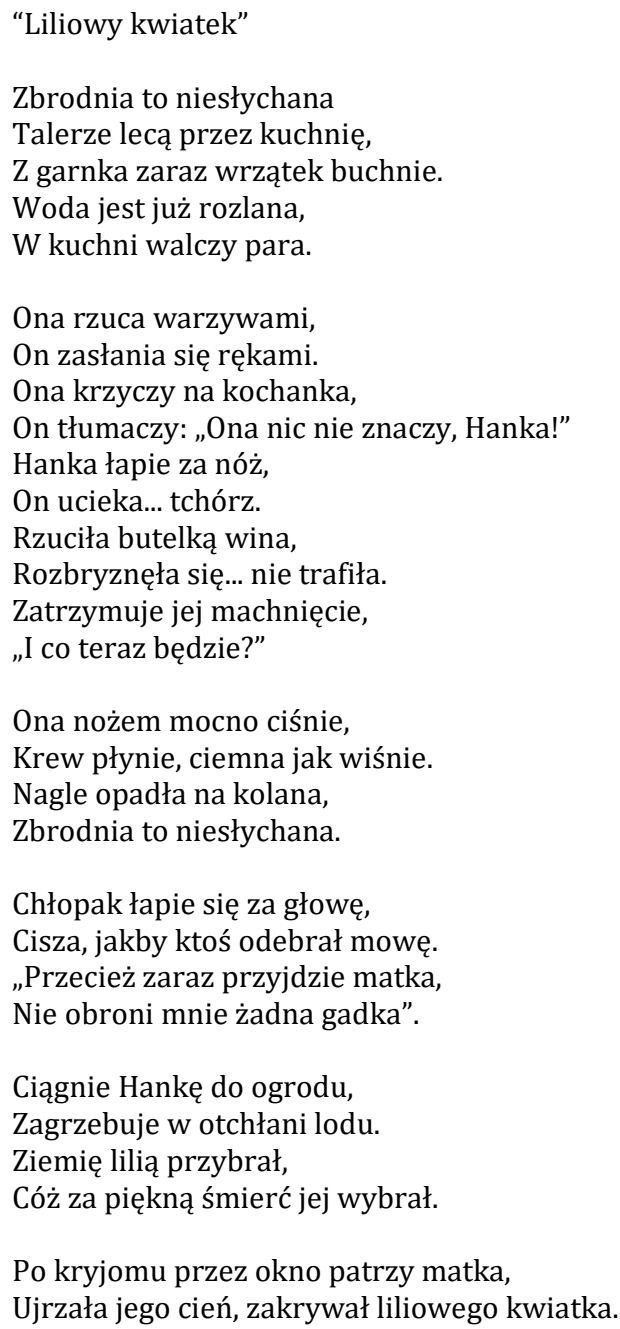


Szybko i podstępnie jak płaz,

Zadzwoniła do odpowiednich władz.

A, że pod ochroną są te kwiatki,

Wsadzono gościa za kratki. ${ }^{1}$

The following text is yet another example of the same topic of lilies written by a Polish heritage student:

"Celina”

Celina to kobieta nie dla każdego pana, bo lubi być prezentami obrzucana. Drogie torebki, perfumy, tyle idzie na to fortuny! Znalazł się jeden bogaty, który myślał, że złapie ją na brylanty. Lecz nie tak prędko, bo z pani gustem jest bardzo ciężko. Tyle starań, tyle zachodu, żeby Celinie nie sprawić zawodu, A ona wybrzydza i wyśmiewa, nie chcąc kolejnych perfum od Channela. Ciężko ująć kobiece serce, nie wiadomo komu ta panna wpadnie w ręce. Tylu już panów próbowało, a jej serce nadal zamknięte próchniało. Za dużo brylantów, klejnotów i świecidełek. Nie ma już miejsca dla tych wszystkich pudełek. Zabrakło nawet wiary, że znajdzie się ktoś niebywały. Mężczyzna, który ją ujmie w sposób skromny i życie zmieni w sen cudowny. Tak też lata mijały, aż w końcu znalazł się ten doskonały. Gdy wręczał jej biała lilie, Celina poczuła, że jej serce szybciej bije. Na twarzy pojawił się ciemny rumieniec, nie wiedziała, że ten kwiat oznacza wieniec. Całe życie czekała na te kwiaty, które przyniosły tak wielkie straty. Bo nie wiedziała, że ten pył, sprawi jej alergiczny młyn. Lilie zabiły ją zanim dotarła do kobierca. Lilie, na które czekała przez całe życie. Teraz lilie rosną na jej grobie symbolizując jej szczęście i krótką przygodę.

A similar written activity may be repeated using other poems, for example Lenartowicz's "A Golden Cup," a touching poetic work that had a great impact on Maria Pawlikowska-Jasnorzewska. She was deeply affected by the great Mazovian lyric poet's verses and she wrote a poem entitled "Lenartowicz" (Lenartowicz 284). Thus, heritage learners read "A Golden Cup" and "Lenartowicz," and then they render their own interpretation of the lyrical verses, just as in this brief poetic work written by a student from my Advanced Polish Composition and Conversation class:

\footnotetext{
1 The texts "Liliowy kwiatek," “Celina," "Złoty kubek Urszula Kochanowska," and "Okno" cited in this paper were written by Polish heritage students enrolled in the Advanced Polish Composition and Conversation class at the University of Illinois at Chicago (Polish 402) in 2012. Please note that students' consent to publish their work in this report has been received.
} 


\section{"Złoty kubek"}

Bywa, że patrzą w górę.

marzą, widzą chmury.

Bywa, że stoją na dachu,

patrzą w dół bez strachu.

Bywa, że to ci sami,

co zapominają, że nie są sami.

Bywa, że to żałości grudka.

bo nie dostrzegli złotego kubka

Most Polish heritage speakers are familiar with Jan Kochanowski's masterpieces Treny (Laments); hence they are eager to learn that Leśmian, a brilliant Polish Jewish poet wrote his commentary in verse, a mini-drama on the Laments entitled Urszula Kochanowska that describes Urszula's arrival in Heaven and her wish to return home to Czarnolas (Leśmian 1067). The figure of Urszula inspired one of my students who wrote the following lines:

\footnotetext{
"Urszula Kochanowska"

Urszula w anielskie niebiosa wstąpiła

Miejsce na ziemi komuś innemu ustąpiła

„Podejdź Urszulo, szepnij na uszko

powiedz co pragniesz, a wszystko nań zrobię

Aby Cię dalej przytrzymać przy sobie."

„Nie pragnę zbyt wiele, lecz w nieb Twoich krasie

Chciałabym poczuć się jak tam w Czarnolasie."

Po chwili namysłu, chwili skupienia

Powstał wręcz idealny obraz sklepienia.

Dom piękny, jak dwie krople wody wykapany

Nawet te same meble, obrazy i ściany.

„Radość w mych oczach jest nieskończona

Moja nadzieja została spełniona,

Weń, czekać tylko aż rodzice nadejdą

Serce me radością do syta napełnią.

Sekundy ciągną się jak godziny, odliczam w panice.

Ktoś puka. Otwieram - to Bóg, a nie rodzice!"
}

A reading and discussion of Rafał Wojaczek's well-known poem "Okno" (Window) (Marx 212) in class gave a motivation for the creation of the following verses composed by yet another heritage speaker in my Advanced Polish Composition and Conversation course:

"Okno"

Jesteś za wysoko i próbuję znaleźć drogę by napisać 


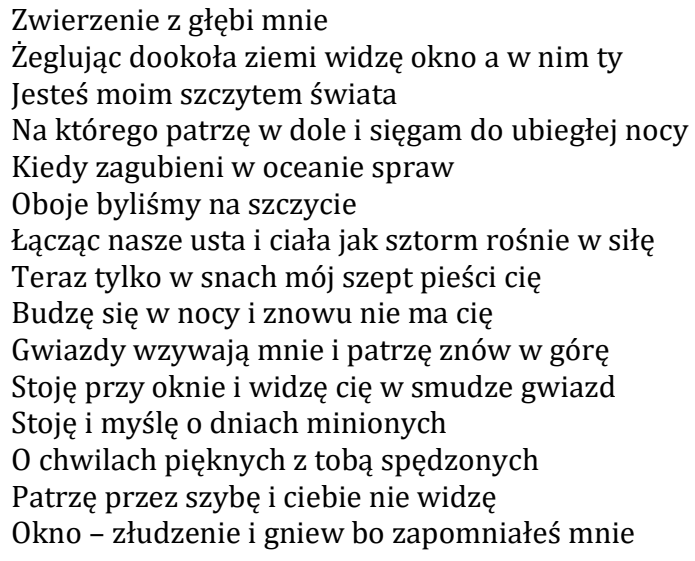

In addition to poems and ballads, Polish heritage students read and discuss a chosen myth. One example is Orpheus and Eurydice. Students examine various versions of literary texts, such as Miłosz's poem "Orpheus and Eurydice," Zbigniew Herbert's mythical tale "H. E. O" (Eos), Leszek Kołakowski's "Apologia Orfeusza, śpiewaka i błazna" (Apology of Orpheus, a Songster and a Jester). Students are usually startled by the unique interpretations of the Orpheus and Eurydice myth and all the different versions of literary texts written in verse and prose.

Poetic texts immersed in Polish inter-textual space are open and may be read in many ways, beyond their initial contexts, presenting many interpretations, offering intellectual adventures and at the same time serious discussions on the theme of crime, violence, death, adultery, and punishment. Poems, ballads, mythical tales are excellent learning sources for the creativity stage in the art of writing transmuting elements of past Polish culture and literature to Polish heritage speakers in a modern language class. At first, some students are greatly surprised by certain topics depicted in the chosen literary works, but after reading original texts, they open up and compose their own stories, sometimes even poems, focusing on their knowledge of the language.

Works Cited

Białoszewski, Miron. “Lilie." Postscriptum, vol. 35-36, 2000, p. 92.

Brzechwa, Jan. Brzechwa Dzieciom. Oficyna Wydawnicza G\&P, 2010.

Cudak, Romuald. "Edukacja Literacka na Kursach Języka Polskiego jako Obcego."

Sztuka i Rzemiosło. Nauczyć Polski i Polskiego, edited by Aleksandra Achtelik et al., vol. 2, Wydawnictwo Gnome, 2010, pp. 117-30. 
--.."Tekst Poetycki w Edukacji Literackiej i Językowej Cudzoziemców.” Postscriptium, vol. 35-36, 2000, pp. 85-93.

Herbert, Zbigniew. Król Mrówek. Prywatna Mitologia. Wydwanictwo a5, 2001.

Kołakowski, Leszek. “Apologia Orfeusza, Śpiewaka i Błazna.” Bajki Różne. Opowieści Biblijne. Rozmowy z Diabłem, Aneks Publishers, 1987.

Kubiak, Bogusław. Na Łamach Prasy. vol. 1, Universitas, 2009.

---. Na Łamach Prasy. vol. 2, Universitas, 2009.

Kuciak, Agnieszka. "Pani Zabija Pana. Ballada Elektroniczna." Dalekie Kraje. Antologia Poetów Nieistniejących, Wydawnictwo Znak, 2005, pp. 58-59.

Lenartowicz, Teofil. "Złoty Kubek." Poezja Polska w Szkole Średniej od Średniowiecza do Współczesności. Antologia, edited by Jerzy Polanicki, Wydawnictwo Edikama, 1993, pp. 152, 284.

Leśmian, Bolesław. “Urszula Kochanowska.” Nad Leśmianem Wiersze i Analizy, edited by Jacek Trznadel, Wydawnictwo Arkana, 1999, pp. 106-7.

Lipińska, Ewa. Nie Ma Róży bez Kolców. Universitas, 2009.

Majkiewicz, Anna, and Jolanta Tambor. Śpiewająco po Polsku. Wydawnictwo Uniwersytetu Śląskiego, 2009.

Marx, Jan. Legendarni i Tragiczni. Eseje o Polskich Poetach Przeklętych. Wydawnictwo Alfa, 1993, p. 212.

Mickiewicz, Adam. "Lilije.” Wybór Poezyj, edited by Czesław Zgorzelski, vol. 1, Zakład Narodowy im. Ossolińskich, 1986, pp. 166-78.

Miłosz, Czesław. Orfeusz i Eurydyka. Wydawnictwo Literackie, 2002.

Norwid, Cyprian Kamil. "Fortepian Chopina." Poezja i Dobroć. Wybór z Utworów, Państwowy Instytut Wydawniczy, 1981, pp. 470-73.

Pięcińska, Anna. Co Raz Wejdzie do Głowy - Już z Niej Nie Wyleci, Czyli Frazeologia Prosta i Przyjemna. Universitas, 2006.

Ruszer, Andrzej. Oswoić Tekst Podręcznik Kompozycji i Redakcji Testów Użytkowych. Universitas, 2011.

Seretny, Anna. "Nauka o Literaturze i Teksty Literackie w Dydaktyce Języka Polskiego jako Obcego/Drugiego." Z Zagadnień Dydaktyki Języka Polskiego jako Obcego, edited by Ewa Lipińska and Anna Seretny, Universitas, 2006, pp. 243-79.

Słowacki, Juliusz. Balladyna. Zakład Narodowy im. Ossolińskich, 1976.

---. Lilia Weneda. Zakład Narodowy im. Ossolińskich, 1986.

Tuwim, Julian. Wiersze dla Dzieci. Prószyński i S-ka, 2010.

Wójcikiewicz, Marek. Piszę, Więc Jestem. Podręcznik Kompozycji i Redakcji Tekstów. Nakładem Uniwersytetu Jagiellońskiego, 1993.

Woźniak, Tadeusz. Ballady polskie. Polskie Radio, 2003. 